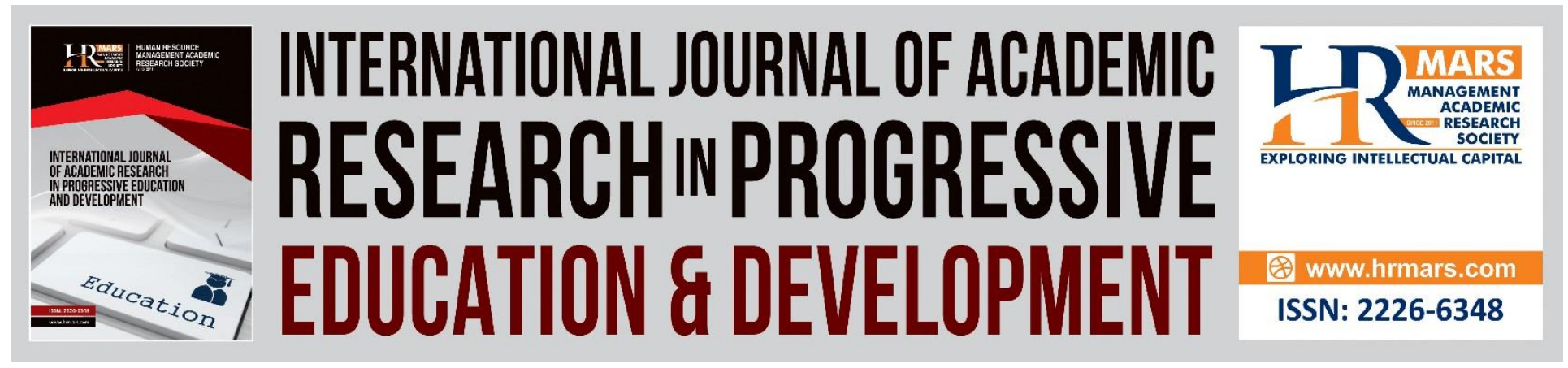

\title{
The Effect Of Knowledge Management Capacity In Innovation Performance
}

\author{
Nurmaisari Binti Che Anuar, Mohd Sazili Bin Shahibi
}

To Link this Article: http://dx.doi.org/10.6007/IJARPED/v7-i3/4369

DOI: $10.6007 /$ IJARPED/v7-i3/4369

Received: 01 June 2018, Revised: 21 June 2018, Accepted: 03 July 2018

Published Online: 26 July 2018

In-Text Citation: (Anuar \& Shahibi, 2018)

To Cite this Article: Anuar, N. B. C., \& Shahibi, M. S. Bin. (2018). The Effect Of Knowledge Management Capacity In Innovation Performance. International Journal of Academic Research in Progressive Education and Development, 7(3), 314-326.

Copyright: (c) 2018 The Author(s)

Published by Human Resource Management Academic Research Society (www.hrmars.com)

This article is published under the Creative Commons Attribution (CC BY 4.0) license. Anyone may reproduce, distribute, translate and create derivative works of this article (for both commercial and non-commercial purposes), subject to full attribution to the original publication and authors. The full terms of this license may be seen

at: http://creativecommons.org/licences/by/4.0/legalcode

Vol. 7, No. 3, July 2018, Pg. 314 - 326

http://hrmars.com/index.php/pages/detail/IJARPED

JOURNAL HOMEPAGE

Full Terms \& Conditions of access and use can be found at http://hrmars.com/index.php/pages/detail/publication-ethics 


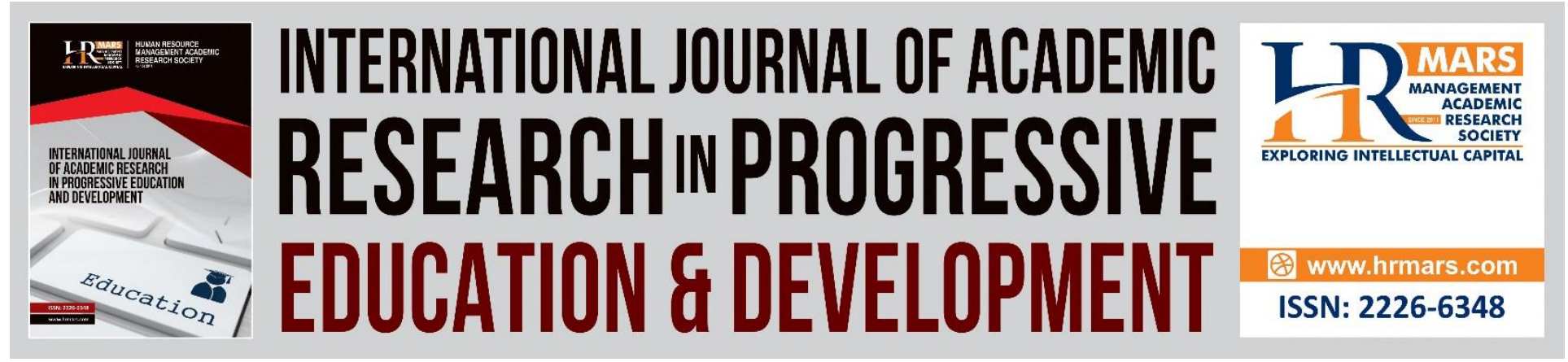

\title{
The Effect Of Knowledge Management Capacity In Innovation Performance
}

\author{
Nurmaisari Binti Che Anuar ${ }^{1}$, Mohd Sazili Bin Shahibi ${ }^{2}$ \\ Faculty of Information Management, MARA University of Technology (UiTM), UiTM, Selangor, \\ Malaysia. \\ Email: ${ }^{1}$ nurmaisari29@gmail.com,mohdsazili@salam.uitm.edu.my
}

\begin{abstract}
Some of employees at the organizations did not apply their knowledge for improved performance and create new innovation. The purpose of this research is to study the effect of knowledge management capacity in innovation performance at the academic institution. There also to examine the effect of knowledge management capacity towards four variables which are dynamic capability, absorptive capability, technology, and innovation performance. In this study, it will discuss about the relationship between the innovation performance among the staff. These studies were using quantitative method approach and the data collection was collected through questionnaires distribution. There are several previous literature are been reviewing as a supporting details to adapt and adopt the framework of this research. In presenting the result, the data was analyses by using Statistical Package for Social Sciences (SPSS) version 22. The pilot test was been conducted by 30 respondents to test the reliability of each variable in the questionnaires. As a result of the findings shows that the have positive significant between the relationship of each variables.

Keywords: Dynamic capability, Absorptive capability, Technology, Innovation capability, Innovation Performance, Information Management, Library Science.

\section{Introduction}

The effect of knowledge management capacity in innovation performance towards employees is essential for organization sustainability in challeinging economy landscape. Knowledge Management (KM) has been widely recognised and practiced in many organization around the world (Mohd Sazili Shahibi, Norazura Yusof et all, 2016). Knowledge capacity also known as knowledge management capacity also including the knowledge sharing, knowledge acquisition and knowledge application. According to Scarbrough (2003), knowledge management is likely such a value added approach of more actively leveraging the knowledge and expertise to create value and enhance organizational effectiveness. Knowledge management capacity will be the main role in supporting the innovation performance in organization. According to (Nonaka \&
\end{abstract}


Takeuchi, 1995), the innovation is not a one act drama for companies the process view on knowledge management and innovation is prevalent in the domains of engineering and management. According to Banbury \& Mitchell (1995), innovation is a key driver and a main source of competitiveness and competitive advantage which is well documented in the literature with a positive impact on firm performance and firm survival. To identify this problem, there are several problem statement have been discuss which is an organization did not have enough employee are innovation in performance and the employees did not reuse the existing knowledge. These problem statements are defined because there are some organizations did not performance their innovation in management and did not realize the innovation at the organization. The ability of a firm to identify the value of outside knowledge, absorb it and use it to its advantage can enhance organization innovation performance (Cohen and Levinthal, 1990). Besides that, the employee has the knowledge but they did not integrate and improve the knowledge for their works. According to Zahra and George (2002) further developed the concept of absorptive capacity to include the organizational routines and processes by which firms operate and manage knowledge. The innovation capability is ability to create and work the new technology through economic practices.To achieve the purpose of research topic, research will conducted several research objectives that are related which is

- To investigate the knowledge management capacity in innovation performance.

- To identify the effect of knowledge management capacity in innovation performance of dynamic capability, absorptive capability, technology, and innovation capability.

\section{Literature Review}

\section{Dynamic Capability}

According to Teece et. al (1997), the term dynamic refers to the capability to regenerate competences that correspond with the changing environment; the term capability emphasizes on the adaptation, integration, and reconfiguration of both internal and external organizational resources in response to the changing environment. Dynamic capabilities focus on the capability to constantly integrate and reconfigure resources in order to gain competitive advantage under a changing environment (Teece et al., 1997). Dynamic capability is focus on the capability to integrate the resources in order to gain the competitive advantages of the changing environment. The concept of dynamic capabilities has been extensively examined to determine if it leads to a difference in performance between firms (Zott, 2003).

Besides that, dynamic capability is the key roles of knowledge resources and learning mechanism. The knowledge resource is a critical strategic resource that has a high propensity for contributing to obtaining competitive advantage (Grant, 1996). Meanwhile, according to Zollo and Winter (2002), Learning mechanisms improve dynamic capabilities and offer an insight into the evolution of dynamic capabilities. Dynamic capability also can creating, integrating and redeploying the knowledge resources according to what organization want. According to Wang et al. (2007) indicate that knowledge-based dynamic capabilities include knowledge absorption, knowledge creation, knowledge storage, and knowledge application. AN organization that contains dynamic capability can integrate and redeploys the knowledge resources and the result will be better than before. 


\section{Absorptive capability}

According to Gray (2006), they termed this the firm's absorptive capacity, a concept that has subsequently been broadened to include a firm's overall capacity for learning, implementing new knowledge, disseminating new knowledge internally and making use of new resources, including new technologies. The function of the absorptive capability is the organization uses the existing resources, the existing tacit knowledge and explicit knowledge at organization, the internal routines at organizations, the management competences and also the culture at the organization. According to Zahra and George (2002) further developed the concept of absorptive capacity to include the organizational routines and processes by which firms operate and manage knowledge.

Besides that, absorptive capability is one of the techniques to improve the skills of the employees when they apply and use it in routine work. It also can improve the knowledge that existing for our future reference and make as new resources. According to Hamel (1991), the concept of absorptive capacity can be used in order to gain a better understanding of the dynamics of a marketing relationship, and contributes to a more contemporary approach to the ideas put forward. The capability to learn from relationship partners is often referred to as a firm's absorptive capacity.

\section{Technology}

Technology is being presented as something new as it drives change at an ever-increasing rate. Technology is the main role of the organization in gathering the information. When having the technology, it easier the organization to know the update information. Besides that, by having technological they can learn new thing through search engine. According to Chan (2000), Information technology (IT) is the convergence of computing, telecommunications and imaging technologies has had radical impacts on IT users, their work, and their working environments. In its various forms, technology can be used for several things which is in processing the data, gathers information, stores collected materials, accumulates knowledge, and expedites communication. Even technology is the main roles in many ways, but it will not operations for every day. Some author observing that technology is now taking significant roles in business processes creating new needs, causing new product development, and commanding new procedures. Besides that, it will may these internal changes that may leads to marketing and others.

\section{Innovation Capability}

Innovation process is involving several processes which are the acquisition, dissemination, and implementation of new or existing knowledge. Organization innovative is closely associated with its ability to utilize its knowledge resources (Subramaniam \& Youndt, 2005). There have three most frequently studied innovation capabilities that can be investigate through innovation aspects which is product, process, and administrative innovation. According to Salaman and Storey (2002), today innovation is regarded as an important mechanism to be more competitive and to survive in global business world. Eren (1982) argues that innovation provided companies with several strategic advantages such as 
eliminating costs, differentiation through new product and services development and increased quality.

According to Burgelman et al., (2004), defined innovation capability as comprehensive set of characteristics of an organization that support and facilitate innovation strategies. It also have the ability in creating and working the new technological through economic practices. Innovation capability as the ability to routinely achieve innovative outcomes (Wallin et al., 2011). Is also important for sustainable competitive advantages. This research regards innovation capability as the performance of the enterprise going through various types of innovation to achieve an overall improvement of its innovation capability (Liao et al., 2009).

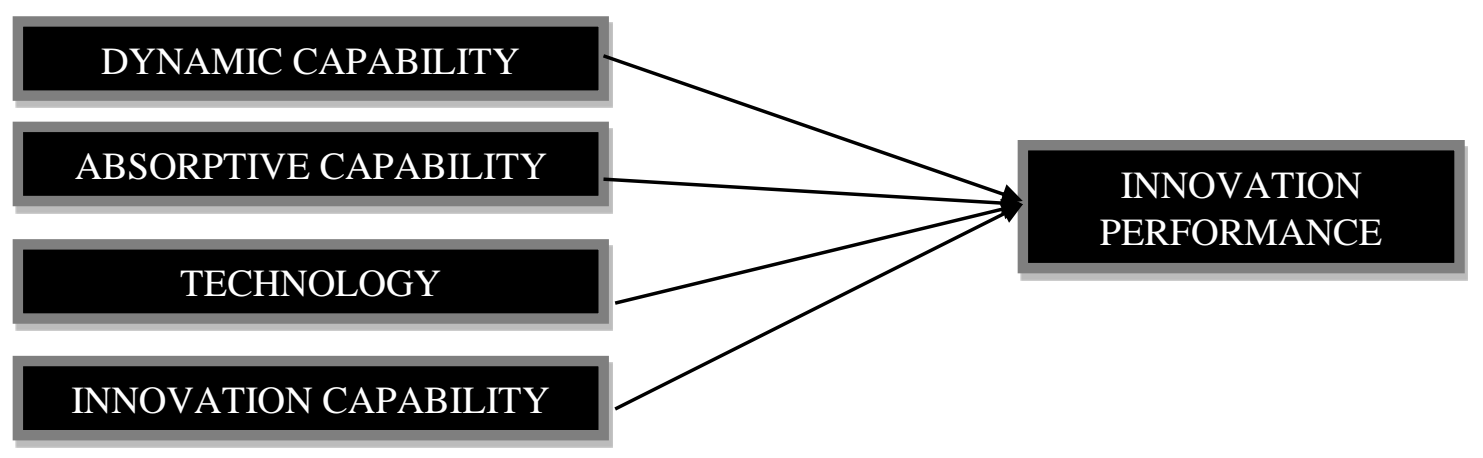

Figure 1: Framework of KM capacity in Innovation Performance

\section{Methodology}

In methodology, it has been discuss several methods to complete this research such as research paradigm, method and others. For the research paradigm is been use positivist because it related to quantitative research which is to test the hypothesis the objectives of this research. According to Nokuthaba (2009), quantitative research focuses on gathering numerical data and generalizing it across groups of people. Meanwhile, the population and sampling for quantitative research tends to produce on probability sampling techniques and the sampling techniques are simple random sampling. Simple random sampling, each member of population is equally likely to be chosen as part of the sample. Besides that, for the instrument these researches are used the questionnaires survey because questionnaire is the primary sources in collects the data. The questionnaire will develop based on theoretical framework that has been proposed by researcher. The selected respondents of the population samples are the employees at academic institution. The questionnaires are straightforward and brief questions. After collecting the data from questionnaires, it will key-in the data in Statistical Package for the Social Science (SPSS). This method will easier to analyse the data that are collected from repondents. It will be conducted a descriptive frequency analysis which is the standard deviations, frequencies and the means of the data because to more understand the characteristics of the sample. Then, a correlation matrix table will be produced to identify the linear between the dependent and independent variables used in the research. The most appropriate statistical tests used by the researcher were 
Vol. 7, No. 3, July 2018, E-ISSN: 2226-6348 @ 2018 HRMARS

t-tests, multiple regressions and correlation used for the data analysis to test the relationships between independent and dependent variable as recommended by Sekaran (2010).

\section{Anaylisis and Discussion}

In this section, it will discuss about the research findings from the previous chapter which is the reliability analysis that have been done. To get the value of the Cronbach Alpha, the questionnaires were distributed to 80 respondents at the academic institution to know the reliable and indicate good accuracy value to run the research. In reliability analysis, it will found the Cronbach Alpha analysis the value for each of the variables that stated on the table below. The highest Cronbach Alpha values are 0.919 which is innovation performance from dependent variables. Meanwhile, for the lowest value of the Cronbach Alpha is technology which 0.812 .

Table 1: Cronbach Alpha

\begin{tabular}{|l|c|c|}
\hline \multicolumn{1}{|c|}{ VARIABLES } & NUMBER OF ITEMS & $\begin{array}{c}\text { CRONBACH'S } \\
\text { ALPHA }\end{array}$ \\
\hline Dynamic Capability & 4 & 0.902 \\
\hline Absorptive Capability & 4 & 0.876 \\
\hline Technology & 4 & 0.812 \\
\hline Innovation Capability & 3 & 0.828 \\
\hline Innovation Performance & 5 & 0.919 \\
\hline
\end{tabular}

In frequency analysis, it discuss about the summary of the respondents profile for 82 respondents that answering the questionnaires in this research. There are nine sections that have been discuss which are gender, age, education, position, years of experiences, types of method, the usage of IT, application used, and ways to share. In gender section, the statistics show that female is highest respondents than male which is 53 respondents from 82 respondents. For the percentages of female is $64.6 \%$ and male is $35.4 \%$. For the age sections, it show that the average age is above 35 years old is the highest value of the respondents. The percentages of the age above 35 years is $67.1 \%$ which 55 respondents from 82 respondents. The second highest is age around $31-31$ years which is 21 respondents and the average is $25.6 \%$. Next is the summary of the education level of respondents which are having four levels such as STPM/Diploma, Degree, Master, and PHD. The highest level of education of respondents is Master which is $45.1 \%$ from 37 respondents, meanwhile for the lowest is Degree which $11.0 \%$ from 9 respondents. Besides that, for the position level of respondents have divide by three which are academic, administration and top management. Academic level is the highest of the respondents which $73.2 \%$ from 60 respondents, and the lowest is top management which $6.1 \%$ from 5 respondents. The average is administration which $20.7 \%$ from 17 respondents. Then, for the years of experiences show that there are five level such as 0-5years, 6-10years, 11-15years, 16-20years and 21 years and above. The highest years of experience from the respondents is $0-5$ years which $48.8 \%$ from 40 respondents and the lowest have two which are 16-20years and 21 years and above is $1.2 \%$ from 1 respondent.

In frequency analysis also discuss about the title of the research are been related such as the method, the application and others. For the types of methods have divide by two which is mobile and desktop. The respondents more prefer using the desktop than mobile which is $65.9 \%$ from 
$100 \%$ of the respondents. The mobile method percentages are $34.1 \%$ from 28 respondents. For the usage of IT, the respondents react to yes which $86.6 \%$ from 71 respondents and $13.4 \%$ from 11 respondents say no. For the application used have six ways that can be choose by the respondents which is company website, email, expert system, internal electronic bulletin board, intranet and knowledge portal. The highest applications are Intranet which $46.3 \%$ from 38 respondents meanwhile the lowest is internal electronic bulletin board which $2.4 \%$ from 2 respondents. The last is ways share the knowledge which has five ways such as colloquium, conference, discussion, meeting and seminar. The highest ways in sharing is discussion which 41.5\% from 34 respondents and the lowest is colloquium which 1.2\% from 1 respondent.

In descriptive analysis, there are analyses the mean and standard deviation for each variables which is dynamic capability, absorptive capability, technology, innovation capability and innovation performance. For each variable have the highest and lowest mean to measure the reliability of the research. The first variables is dynamic capability which is the highest mean is $i$ have the opportunity to improve the existing knowledge which 4.10. The highest mean for second variable, absorptive capability is i am able to reuse the new knowledge such as technology which value of mean is 4.17 and the third variables is technology with the highest mean is $i$ am able to use more than one search engine to find information with mean 4.34. Meanwhile, for the fourth variable is innovation capability, the highest mean is $i$ am able to creating and working the new technology based on economy practices with the value of mean 4.02 and the last variables is innovation performance with the highest mean is 4.28 , knowledge management capacity can increase employees performance.

In correlation analysis, it has been chosen the Pearson Correlation analysis to test the relationship between the variables. In Pearson Correlation analysis, it shows that the correlation coefficient of independent variables is strong. It is can the innovation performance is positively with the dynamic is $0.589 * *$, absorptive are $0.576^{* *}$, technology is $0.499^{* *}$ and innovation is $0.613^{* *}$. There is positive between the relationship of the independent variables and dependent variables. 
INTERNATIONAL JOURNAL OF ACADEMIC RESEARCH IN PROGRESSIVE EDUCATION AND DEVELOPMENT

Vol. 7, No. 3, July 2018, E-ISSN: 2226-6348 @ 2018 HRMARS

Table 2: Correlation analysis

\begin{tabular}{|c|c|c|c|c|c|c|}
\hline & & ALL_DYNAMIC & ALL_ABSORPTIVE & ALL_TECHNOLOGY & ALL_INNOVATION & ALL_PERFORMANCE \\
\hline \multirow[t]{3}{*}{ ALL_DYNAMIC } & $\begin{array}{l}\text { Pearson } \\
\text { Correlation }\end{array}$ & 1 & $.824^{* *}$ & $.679^{* *}$ & $.725^{* *}$ & $.589^{* *}$ \\
\hline & $\begin{array}{l}\text { Sig. (2- } \\
\text { tailed) }\end{array}$ & & .000 & .000 & .000 & .000 \\
\hline & $\mathrm{N}$ & 82 & 82 & 82 & 82 & 82 \\
\hline \multirow[t]{3}{*}{ ALL_ABSORPTIVE } & $\begin{array}{l}\text { Pearson } \\
\text { Correlation }\end{array}$ & $.824^{* *}$ & 1 & $.739^{* *}$ & $.664^{* *}$ & $.576^{* *}$ \\
\hline & $\begin{array}{l}\text { Sig. (2- } \\
\text { tailed) }\end{array}$ & .000 & & .000 & .000 & .000 \\
\hline & $\mathrm{N}$ & 82 & 82 & 82 & 82 & 82 \\
\hline \multirow[t]{3}{*}{ ALL_TECHNOLOGY } & $\begin{array}{l}\text { Pearson } \\
\text { Correlation }\end{array}$ & $.679^{* *}$ & $.739^{* *}$ & 1 & $.629^{* *}$ & $.499^{* *}$ \\
\hline & $\begin{array}{l}\text { Sig. }(2- \\
\text { tailed) }\end{array}$ & .000 & .000 & & .000 & .000 \\
\hline & $\mathrm{N}$ & 82 & 82 & 82 & 82 & 82 \\
\hline \multirow[t]{3}{*}{ ALL_INNOVATION } & $\begin{array}{l}\text { Pearson } \\
\text { Correlation }\end{array}$ & $.725^{* *}$ & $.664^{* *}$ & $.629^{* *}$ & 1 & $.613^{* *}$ \\
\hline & $\begin{array}{l}\text { Sig. (2- } \\
\text { tailed) }\end{array}$ & .000 & .000 & .000 & & .000 \\
\hline & $\mathrm{N}$ & 82 & 82 & 82 & 82 & 82 \\
\hline \multirow[t]{3}{*}{ ALL_PERFORMANCE } & $\begin{array}{l}\text { Pearson } \\
\text { Correlation }\end{array}$ & $.589^{* *}$ & $.576^{* *}$ & $.499^{* *}$ & $.613^{* *}$ & 1 \\
\hline & $\begin{array}{l}\text { Sig. }(2- \\
\text { tailed) }\end{array}$ & .000 & .000 & .000 & .000 & \\
\hline & $\mathrm{N}$ & 82 & 82 & 82 & 82 & 82 \\
\hline
\end{tabular}


Regression analysis is a constructive statistical technique that can be used to analyze the association between a set of independent and dependent variables. There are two type regression which is linear regression and multiple linear regression. Multiple regression is used as a type of regression that has single metric dependent variables and several metric independent variables. In multiple linear regressions, there are several results that have been shown such as R. square, ANOVA and coefficients.

For $\mathrm{R}$-square show that the value of $\mathrm{R}$ is 0.659 , means that there are positive linear correlation between the variables. The adjusted $R$ squares is 0.404 . It means that the dependent variables are linear correlation between the variables. The adjusted $R$ squares is 0.404 . It means that the dependent variable is able to explain the changes of the independent variables. Besides that, there also have ANOVA table show the F-ratio. The F-ratio for this model is 14.744 . The F-ratio are explaining the result of compared the amount explained variance. For coefficient table, show that $\mathrm{t}$-value for the innovation is 2.747 . It mean the innovation is most significant variables that others variables.

Table 3: Model summary ( R-square)

\begin{tabular}{|l|r|r|r|r|}
\hline Model & R & R Square & $\begin{array}{c}\text { Adjusted R } \\
\text { Square }\end{array}$ & $\begin{array}{c}\text { Std. Error of } \\
\text { the } \\
\text { Estimate }\end{array}$ \\
\hline 1 & $.659^{a}$ & .434 & .404 & .40245 \\
\hline
\end{tabular}

Table 4: ANOVA

\begin{tabular}{|c|c|c|c|c|c|c|}
\hline \multicolumn{2}{|c|}{ Model } & $\begin{array}{l}\text { Sum of } \\
\text { Squares }\end{array}$ & df & $\begin{array}{l}\text { Mean } \\
\text { Square }\end{array}$ & $\mathrm{F}$ & Sig. \\
\hline 1 & Regression & 9.552 & 4 & 2.388 & 14.744 & $.000^{b}$ \\
\hline & Residual & 12.472 & 77 & .162 & & \\
\hline & Total & 22.024 & 81 & & & \\
\hline
\end{tabular}

Table 5: Cofficients

\begin{tabular}{|c|c|c|c|c|c|c|}
\hline \multicolumn{2}{|c|}{ Model } & \multicolumn{2}{|c|}{$\begin{array}{c}\text { Unstandardized } \\
\text { Coefficients }\end{array}$} & \multirow{2}{*}{$\begin{array}{c}\text { Standardized } \\
\text { Coefficients } \\
\text { Beta }\end{array}$} & \multirow[b]{2}{*}{$\mathrm{t}$} & \multirow[b]{2}{*}{ Sig. } \\
\hline & & B & $\begin{array}{l}\text { Std. } \\
\text { Error }\end{array}$ & & & \\
\hline \multirow[t]{5}{*}{1} & (Constant) & 1.623 & .368 & & 4.410 & .000 \\
\hline & ALL_DYNAMIC & .130 & .143 & .153 & .913 & .364 \\
\hline & ALL_ABSORPTIVE & .169 & .148 & .191 & 1.136 & .259 \\
\hline & ALL_TECHNOLOGY & .029 & .126 & .031 & .230 & .818 \\
\hline & ALL_INNOVATION & .322 & .117 & .356 & 2.747 & .007 \\
\hline
\end{tabular}

There are the hypotheses which are: 
INTERNATIONAL JOURNAL OF ACADEMIC RESEARCH IN PROGRESSIVE EDUCATION AND DEVELOPMENT

Vol. 7, No. 3, July 2018, E-ISSN: 2226-6348 @ 2018 HRMARS

H1: $\quad$ There is positive significant relationship between knowledge capacity and innovation performance.

$\mathrm{H} 2$ : There is positive significant relationship between dynamic capability and innovation performance.

H3: There is positive significant relationship between absorptive capability and innovation performance.

H4: There is positive significant relationship between technology and innovation performance.

H5: There is positive significant relationship between innovation capability and innovation performance.

Based on the discussion above, it shows that the entire hypothesis is positive significant relationship between independent variables and dependent variable.

\section{Conclusion}

This research are been discussed about the effect of knowledge management capacity on innovation performance. The employees did not apply their innovation towards their job scope and not use their skills to improve their works. In this research, there are two objectives of this research which are to determine the knowledge management capacity in innovation performance and to examine the effect of knowledge management capacity in innovation performance of dynamic capability, absorptive capability, technology, and innovation capability. The objective of this research is accepted to the respondents that can be innovation at the organizations. All the variables are accept and suitable to prove that the organizations need innovation performance to improve their working environment.

Besides that, another suggestion is encourage an innovation performance. Innovation performance means that someone can lead the new ideas and approachable the employees about the organizations. In the organization, it should provide the spare time like break time to employees to share their thought about the office environment and others. It also can be allocated time for their employees to break from their routine roles to inspire new thoughts. The organizations should encourage the employees to share their thought or new ideas about the organizations. They should make the ways to ensure the employees share their thought through meeting, discussion or place out the suggest box in the office. Another suggestion is the employees should reuse the existing knowledge because some of the knowledge can be improve and integrate to better. The existing knowledge should be renewing to be more interactive and useful knowledge to ensure it will be used for the future. For example, in organization, some of the knowledge can use by the ways of representing is old ways so it become not interest. The employees should take apart to improve become more attractive and used the knowledge for the future.

Besides that, there are several recommendations are strategies to ensure the employees are alert about the problem on their office environment such as give more the staff more training or workshop to improve their skills and encourage an innovation performance to individual. The first suggestion to overcome this research is give the staff more training or workshop to improve their skills. The organizations should have more training to train the employees to improve the innovation on their performance. By having those training, it will help the employee used their skills and apply in their work. Besides that, when the organization send to training, they did not 


\section{INTERNATIONAL JOURNAL OF ACADEMIC RESEARCH IN PROGRESSIVE EDUCATION AND}

DEVELOPMENT

Vol. 7, No. 3, July 2018, E-ISSN: 2226-6348 @ 2018 HRMARS

apply it and it will useless to the organization. Because of that, the organization should ensure the employees are being train should use their knowledge and apply in their job scope. They also should make innovation improvement in their management such as in teaching. They should make some improvement in teaching methods such as teach the student in new method to ensure the students easy to adapt. By having the training, the employees will gain additional experience and it became benefit to the organization. They also can get new ideas and approaches your employee has learned. As the conclusion, by doing this research, the researcher will learn the difficulty to gather or collect the data from the respondents and the worth in completing this research. There also discussed about the recommendation that organization should take apart to improve the innovation performance in their organizations. In this research, there are some recommendation are been proposed to improve their performance in organization.

\section{References}

Lidija, B. \& Robert, D.H. (2014). Dynamic capabilities vs. innovation capability: are they related?. Journal of Small Business and Enterprise Development. 21(3). 368-384. Retrieved May 24, 2017 from http://dx.doi.org/10.1108/JSBED-02-2014-0018

Wang, C, \& Han, Y. (2011). Linking properties of knowledge with innovation performance: the moderate role of absorptive capacity. Journal of Knowledge Management. 15(5).802-819. Retrieved from May 24, 2017 from http://dx.doi.org/10.1108/13673271111174339

Gray, C. (2006). Absorptive capacity, knowledge management and innovation in entrepreneurial small firms. International Journal of Entrepreneurial Behavior \& Research. 12(6).345-360. Retrieved from

http://dx.doi.org/10.1108/13552550610710144

$\mathrm{Ng}$, D.C.W \& Law, K. (2015). Impacts of informal networks on innovation performance: evidence in Shanghai. Chinese Management Studies. 9(1).56-72. Retrieved from http://dx.doi.org/10.1108/CMS-05-2013-0077

Dictionry.com (2017). Technology. Dictionary.com. Retrieved June 172017 from http://www.dictionary.com/browse/technology

Dudovski, J. (2015). Research methodology: Random Sampling. Necessary knowledge to conduct a business research. Retrieved May 25 2016, from http://researchmethodology.net/sampling/random-sampling/

Govindan Marthandan, G \& Tang, C. M (2010). Information technology evaluation: issues and challenges. Journal of Systems and Information Technology. 12(1). 37 - 55. Retrieved December 14, 2016 from http://dx.doi.org/10.1108/13287261011032643 
INTERNATIONAL JOURNAL OF ACADEMIC RESEARCH IN PROGRESSIVE EDUCATION AND

DEVELOPMENT

Vol. 7, No. 3, July 2018, E-ISSN: 2226-6348 @ 2018 HRMARS

Innovation capability (2008). Dr. Choi's Integral Leadership Center. Retrieved form

http://leadershipcenter.tistory.com/272

Andersén, J. \& Kask, J. (2012) . Asymmetrically realized absorptive capacity and relationship

durability. Management Decision. 50(1).43-57. Retrieved from http://dx.doi.org/10.1108/00251741211194868

Johnston, G., P., \& Bowen, D., V. (2005). The benefits of electronic records management systems: a general review of published and some unpublished cases. Records Management Journal, 15(3). Retrieved May 14 2017, from http://dx /doi/pdfplus/10.1108/09565690510632319

Asgarian, N. (2012). Knowledge management capacity and innovation performance. Management Science Letters 2. 2739-2746. Retrieved form www.GrowingScience.com/msl

Inauen, M. \& Wicki, A. S. (2011). The impact of outside-in open innovation on innovation performance. European Journal of Innovation Management. 14(4).496520. Retrieved June 20, 2017 from https://doi.org/10.1108/14601061111174934

Yunis, M. \& El-Kassar, A-N \& Tarhini, A. (2017). Impact of ICT-based innovations on organizational performance: The role of corporate entrepreneurship.

Journal of Enterprise Information Management. 30(1).122-141. Retrieved June 162017 from https://doi.org/10.1108/JEIM-01-2016-0040

Naqshbandi, M. M. (2016). Managerial ties and open innovation: examining the role of cabsorptive capacity. Management Decision. 54(9).2256-2276. Retrieved from May 24, 2017 from http://dx.doi.org/10.1108/MD-03-2016-0161.

Shahibi, M.S., Yusof, N., Hussin, N., Ali, J., Zaharuddin Ibrahim, Z. \& Shamsul Kamal Wan Fakeh, S.K.W. (2016) Factor Influencing Knowledge Sharing Intention in Enforcement Agency. Internation Journal of Engineering Research and Management (IJERM), Vol 3, Issue 2, Pg 103-111.

Yi Chien, S.Y. \& Tsai, C. H. (2012). Dynamic capability, knowledge, learning, and firm performance. Journal of Organizational Change Management. 25(3). 434-444. Retrieved from May 24, 2017 from http://dx.doi.org/10.1108/0953481121122814

Tseng, S. M. (2016). Knowledge management capability, customer relationship management, and service quality. Journal of Enterprise Information Management.

29(2).202-

221.Retrieved May 24, 2017 from http://dx.doi.org/10.1108/JEIM-04- 2014-0042

Chan, S.L (2000) .Information technology in business processes. Business Process Management $\begin{array}{llll}\text { Journal. } & 6(3) .224-237 . & \text { Retrievedd from }\end{array}$ https://doi.org/10.1108/14637150010325444 
WebFinance. (2015). Employee. Businessdictionary.com. Retrieved June 16 2017, from http://www.businessdictionary.com/definition/employee.html

Chen, X.H., Zhao, K., Liu, X. \& Wu, D.D. (2012). Improving employees' job satisfaction and innovation performance using conflict management. International $\begin{array}{ccc}\begin{array}{c}\text { Management. } \\ \text { https://doi.org/10.1108/10444061211218276 }\end{array} & \text { Retrieved }\end{array}$ Journal of Conflict

Hsiao, Y.C., Chen, C.J., \& Chang, S.C. (2011). Knowledge management organizational performance: the social interaction view. International 32(5/6).645-660. Retrieved May 24, 20, $\quad 2017$ from http://dx.doi.org/10.1108/01437721111158242

capacity and Journal of Manpower. 2017 from

Cao, Y., \& Zhao, L. (2013). Analysis of patent management effects on technological innovation Performance. Baltic Journal of Management. 8(3).286-305. Retrieved from http://dx.doi.org/10.1108/BJOM-May-2012-0033 